\title{
Intermédialités
}

Histoire et théorie des arts, des lettres et des techniques

Intermediality

History and Theory of the Arts, Literature and Technologies

\section{Anarchival Images: The Labour of Chronic Collage}

\section{Alanna Thain}

Numéro 33, printemps 2019

restituer (le temps)

rendering (time)

URI : https://id.erudit.org/iderudit/1065014ar

DOI : https://doi.org/10.7202/1065014ar

Aller au sommaire du numéro

Éditeur(s)

Revue intermédialités

ISSN

1920-3136 (numérique)

Découvrir la revue

Citer cet article

Thain, A. (2019). Anarchival Images: The Labour of Chronic Collage. Intermédialités / Intermediality, (33). https://doi.org/10.7202/1065014ar

\section{Résumé de l'article}

Dans cet essai, je développe le concept de collage chronique à travers une analyse de deux oeuvres récentes de performance médiatique : Nanook of the North de Tanya Tagaq (2012-) et The Green Fog de Guy Maddin et Galen et Evan Johnson (2017). Ces " remixes » sont tous deux des commandes provenant de festivals de films, présentés à titre de performances. Tandis que Tagaq crée une nouvelle bande-sonore résurgente et résistante pour le film ethnographique Nanook of the North de Robert Flaherty, datant de 1922, Maddin échantillonne des films et des séries tournées à San Francisco pour refaire le film Vertigo d'Alfred Hitchcock, produit en1958, sur une bande-son signée par Kronos Quartet. À travers une approche écosophique, cet essai décrit le collage chronique comme une technique critique anti-extractiviste qui rassemble les archives vivantes des mémoires médiatiques traversant des sites d'expropriation, d'exclusion et d'histoire contestée. Comme forme dynamique, le collage chronique désigne la tentative d'animer l'agentivité affective d'objets temporels. 


\title{
Anarchival Images: The Labour of Chronic Collage
}

\author{
Alanna Thain
}

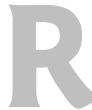

eanimating audiovisual archives through remixes requires an ecosophical approach, connecting knowledge practices to inventive projects of worldmaking. ${ }^{\text {I }}$ This approach includes the forces of memory, affect, and embodiment as material and immaterial components of creation. It attunes us to time as a still-acting element of how we live our mediated memories, through nonsensuous perceptions of pastness affecting the present. As contemporary cinema experiences ongoing ontological disorientations across shifting platforms, a renewed critical and creative interest in exploiting the zone between the recorded and live has emerged. Heterogeneous sites of screening proliferate, making cinematic affect move transversally between onscreen and off. While such extra-cinematic sites may not be new, levelling their hierarchy destabilizes what counts as a properly cinematic experience, generating new "collaborative remix zones” where "plural pasts, multiple temporalities, multiple artefacts, and polyvocalities can join together to reclaim public spaces." ${ }^{\prime 2}$ A new intensity of remodulation, accelerated by digital technologies, makes cinema recomposable, producing variations on "generative cinema" (a label that productively emphasizes the creativity of new combinatory forms). ${ }^{3}$ The reperformance of cinematic texts extends beyond the screen's frame, as

${ }^{\mathrm{I}}$ In this essay the notion of ecosophy comes from the work of Félix Guattari. Guattari sought ways of reinventing human existence through techniques to change our mental, social, and environmental ecologies. It is this transversal logic of ecology that I wish to evoke here. See Félix Guattari, The Three Ecologies, transl. by Ian Pindare and Paul Sutton, London, Bloomsbury, coll. "Bloomsbury Revelations," 2005.

${ }^{2}$ Dale Hudson and Patricia Zimmermann, "Cinephilia, Technophilia and Collaborative Remix Zones," Screen, vol. 50, no. I, 2005, p. 135, full text available at:

https://academic.oup.com/screen/article/50/I/I35/1631620?searchresult $=\mathrm{I} \quad$ (accessed 22 March 2019).

3 Dejan Grba, “Avoid Setup: Insights and Implications of Generative Cinema," Journal of Science and Technology of the Arts, vol. 9, no. I, August 2017, p. 384-393. 
embodiment-gesture, breath, memory, and movement-modulates media as a dynamic form. I explore this dynamic form as chronic collage, through two recent works of media reperformance: Tanya Tagaq's Nanook of the North (20I2-) and Guy Maddin, Evan Johnson, and Galen Johnson's The Green Fog (20I7), ${ }^{4}$ as compositions of time, part of the enduring ephemeral relation of festivals to archival practices.

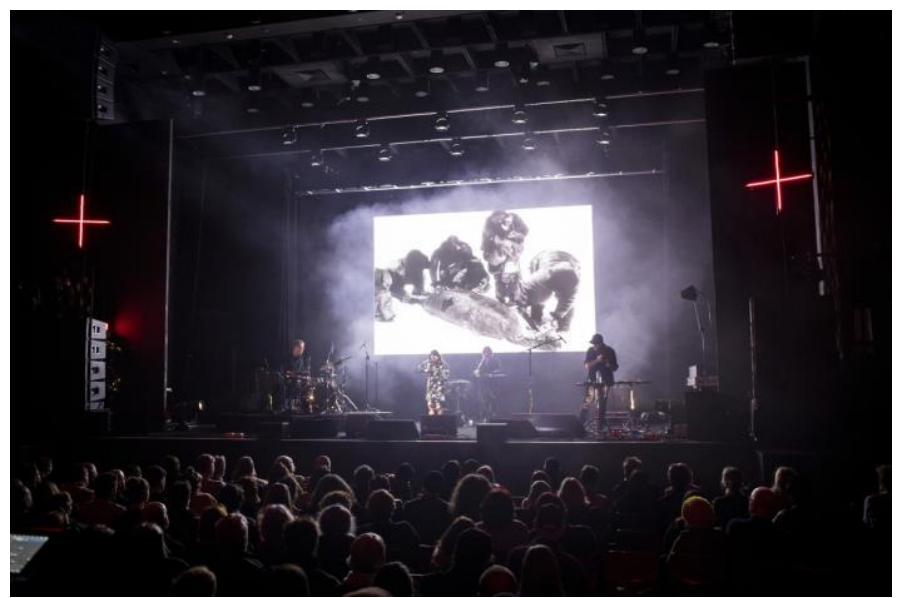

Fig. I. Tanya Tagaq, Nanook of the North at the Dark Mofo Festival, June 8, 20r8. Photo Credit: Dark Mofo/Rémi Chauvin. Image: Courtesy of Dark Mofo, Hobart, Tasmania, Australia.

${ }^{4}$ Though The Green Fog is a collaborative effort by Maddin and the Johnson brothers, for the sake of brevity, and because most of the points of comparison in this essay address previous work where Maddin was the sole director, I refer to The Green Fog throughout as Maddin's film. This choice both replicates and raises questions about normative ascriptions of authorship (and the performance of authorship) that are radically challenged by the form of the film itself, which I will discuss in a future, expanded version of this work. Publicity materials for a previous collaboration by Maddin and the Johnsons, Bring Me the Head of Tim Horton (2015), describes that work as "[g]uided by the spirit of Evan Johnson's Cuadecec Manifesto (which calls for makings-of en masse)." In an interview with Maddin and Evan Johnson around their co-directed effort The Forbidden Room (2015), Johnson notes that "I never actually wrote the manifesto. We just conceived it. While we were in Jordan shooting Bring Me the Head of Tim Horton, we just decided that the best making-of film possible could be at every opportunity to put our cameras next to the main film's and we could edit their film together, with a boom mic here and images of their crew. It's essentially a parasite's aesthetic. You've just stolen their production values." This "parasitic" relationship is evidently at work, in a different format, with The Green Fog. See Steve Erickson, "Interview: Guy Maddin and Evan Johnson on The Forbidden Room," Slant Magazine, 4 October 2015. https://www.slantmagazine.com/film/interview-guy-maddin-and-evan-johnson/ (accessed May 29, 2019). 


\section{Chronic Collage as Tactic OF TEMPORAL InTIMACy}

$\mathbf{I}_{2}$

Tagaq is from Cambridge Bay, Nunavut, and is one of the most celebrated Inuit artists in the world today, best known for her work as a musician and performer. Her ruthless live remix performance of Robert Flaherty's 1922 film Nanook of the North re-possesses that film's images through a radically embodied, live, and improvised soundtrack. Originally commissioned by the Toronto International Film Festival,5 Tagaq's Nanook has toured since 2012 (see Fig. I). ${ }^{6}$ Before a projection of Flaherty's staged film of Inuit life in the Canadian North, Tagaq and a changing constellation of performers improvise on top of a sonic layer composed of Tagaq's re-processed vocalizations mixed with field recordings from the North, reclaiming the film with an intensive sonic critique.
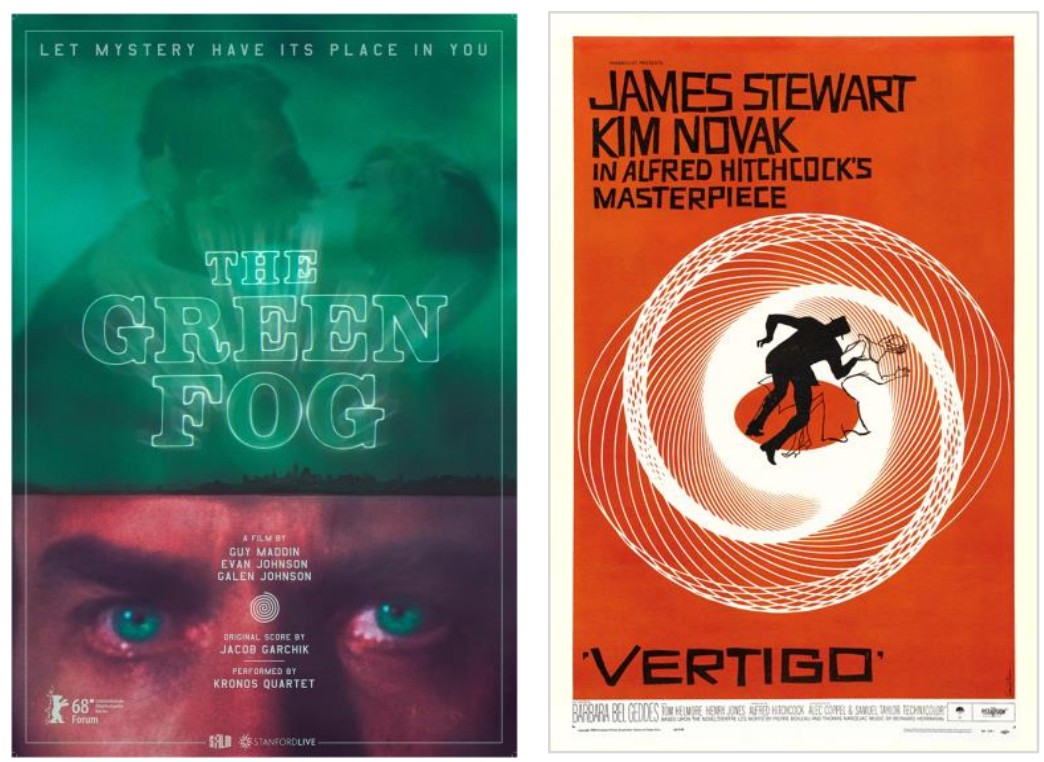

Fig. 2. Poster of the movie The Green Fog (2017). Wikipedia Commons (Public Domain).

Fig. 3. Poster of the movie Vertigo (1958). Wikipedia Commons (Public Domain).

$s$ The performance was commissioned by TIFF Bell Lightbox as part of its film retrospective First Peoples Cinema: Isoo Nations, One Tradition.

${ }^{6}$ This essay draws on two versions: in Montreal at Place des Arts, Cinquième Salle, 19-20

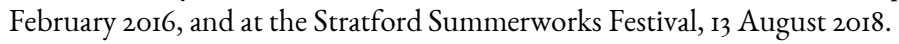



(see Fig. 2 and 3) composed entirely of fragments of other media texts shot in San Francisco, originally performed to a live soundtrack by the Kronos Quartet. ${ }^{7}$ The green fog refers to the neon haze that surrounds the first re-animation of Judy (Kim Novak) as Madeleine in Hitchcock's film, and echoes Hitchcock's own memory of a silent-era tinting technique used to signal supernatural presence. ${ }^{8}$ Both Tagaq's soundscape, occupying the projector's glow as a thick zone of transformation, and Maddin's green fog inhabit ectoplasmic sites that fail to be fully extractable, while also resisting being consigned to a ghostly presence. This resistance to extraction's logic insists on the stickiness of chronic collage, which stages relations between elements so they continue to transform in time.

Both works, originally commissioned by film festivals, are performances that play on lived archives of moving image memory across sites of expropriation, exclusion, and contested history. Both also use the temporality of music and performance to recompose images from within. Maddin describes the film as " a (city) symphony of sampled emulsions and pixels and video noise." 9 Tagaq's fully frontal performance, never looking back at the screen, pushes the film's projected images through a thick "twenty-first century filter" of transformative sound and insistent embodiment, desyncing space, time, and authority. ${ }^{\text {Io }}$ It remixes normative colonialist temporality, which codes the Inuit as disappearing or "already gone" (freeing access to the resources of their land); part of Tagaq's labour of chronic collage is an activist project of recharging the past and claiming both the present and future as Indigenous. ${ }^{\mathrm{II}}$

7 The movie was commissioned by SFFILM and STANFORD LIVE as the closing-night event for the 6oth San Francisco International Film Festival, April I6, 2017. The original score is by Jacob Garchik.

${ }^{8}$ See Donald Spoto, The Dark Side of Genius: The Life of Alfred Hitchcock, Boston, Little, Brown, 1987 [1983], p. 107.

9 Alexander Varty, "VIFF 2017: Guy Maddin Presents a Patchwork Vertigo," The Georgia Straight, 4 October 2017, https://www.straight.com/movies/976301/viff-2017-guy-maddinpresents-patchwork-vertigo (accessed 22 May 2019).

1o Holly Gordon, "Inuk Throat Singer Tanya Tagaq on Reclaiming Nanook of the North," CBC Music, CBC News. January 25, 2014, https://www.cbc.ca/news/indigenous/inuk-throatsinger-tanya-tagaq-on-reclaiming-nanook-of-the-north-I.250858I (accessed 22 May 2019).

II This reflects Tagaq's other work with audiovisual media; as analyzed by Nicole Ashley Dial Kay, it characteristically exhibits "circularity in the narrative" (Nicole Ashley Dial-Kay, Community of the North: Postnationality in Contemporary Arctic Video Art, Master's Thesis, University of Colorado at Boulder, p. 75). 
Via archival materials, both works foreground the anarchival liveliness of media situated between documentation, documentary, and fabulation, raising questions about the ethical stakes of ownership and the claims of images on our lives. I will use the concept of the anarchival, which I have been developing to consider the intersections of embodiment, liveness, and reperformance in transmedial cinema, and expand on fabulation, adapted from the work of Henri Bergson and Gilles Deleuze, later in this essay. ${ }^{\mathrm{I2}}$ Here, the anarchival takes dynamic form as chronic collage, which attempts to animate the affective agency of temporal objects.

An ecosophical analysis attends to the transformational potential of reperformance, considering the ethico-aesthetic work of these remixes as neither predetermining their politics through the lens of identity, nor cordoning off the aesthetic as a depoliticized sphere of free play. Here, chronic collage names what remains in reperformance, opening through narrative onto other stories that insist on being heard. If the remix is often understood according to an extractive ecology of sampling, these works, thick with place (both in terms of content and in their origin as live performance events) and mobile across time (through repetition and replay), exert a transformative temporal drag on extractivist actions.

Chronic collage takes form from an anarchival impulse at once anachronistic and anarchic. Bringing these works together across their shared dynamics and disparate stakes asks us to attend to forms of labour and animacy that make up their ecosophical terrain. Tagaq's work around Nanook's critical relation to appropriation, the colonialist gaze, and modernity's violent epistemological regimes (including cinema), may seem all too legibly political, a perspective amplified by Tagaq's well-known activism around issues such as the seal hunt, racism, and the theft and misuse of her own labour. ${ }^{13}$ To attend to this work's formal qualities is not to sideline its political impact, but to consider how a politics

${ }^{12}$ For further discussion of the "anarchival," see Alanna Thain, "Anarchival Cinemas," Inflexions, no. 4, "Transversal Fields of Experience," December 2oro, http://inflexions.org/n4_Anarchival-Cinemas-by-Alanna-Thain.pdf (accessed 22 May 2019); and Alanna Thain, "Anarchival Impulses: A Performance Theory of Media," Public, vol. 29, no. 57, June 2018, pp. 27-35.

${ }^{13}$ See, for example, Brigid Delaney, "Seal Hunting, Throat Singing, and Fighting Fair: The Power and Purpose of Tanya Tagaq," The Guardian, May 23, 2018, https://www.theguardian.com/culture/20I8/may/23/seal-hunting-throat-singing-andfighting-fair-the-power-and-purpose-of-tanya-tagaq (accessed 22 May 2019). 
of representation is inadequate to Tagaq's claim on both the filmic matter and on the performance's transversal flicker that acknowledges and appreciates a world of survivance in the aftermath of colonial catastrophe. As Macarena Gomez-Barris describes such survivance within "extractive zones," that is, Indigenous ecologies exploited for natural resources: "By highlighting the struggle over representation, the viewer begins to understand the multidirectional sensorium of Indigenous experience that, because it lives on the other side of colonial catastrophe, is always at odds, and defends against ongoing destruction." ${ }^{14}$ Karyn Recollet analyzes Indigenous remix as a movement practice of what she terms "glyphing," which produces "maps to tomorrow as a result of mobilizing multiple geographical/territorial scales.” Is Tagaq's remix mobilizes such multidirectional senses and timing across scales as key aesthetic strategies.

Maddin's film may seem a strange bedfellow to Tagaq's performance, though as a Winnipeg-based artist obsessively reworking that city's cinecorpus, he is deeply invested in reopening fixed place through the work of time, as in his fabulative docufantasia My Winnipeg (2007). The Green Fog re-sites such practices in a cinematic and mental landscape of a city not his own. But the intimate animacies of bodies and environments that emerge produce a related, disjunctive account of what it means to engage, rather than occupy, a non-extractive ambulation. Both melancholic and flattening in its affects, The Green Fog deflates the cinephilic's embalming embrace, freeing bodies and spaces from narrative capture. In their tender and ambivalent returns-as bodies, as spaces-they are not restored, they do not haunt, but regain a fragile material animacy. As with Tagaq's work, such ethico-aesthetics are not adequately described as representational. In the interstices of these works, it is time that is rendered through the disjunctive connections of chronic collage, which decouple and undo hierarchies of sense perception (breaking open/apart image and soundtrack) as well as non-sensuous perceptions of memory and liveness.

${ }^{14}$ Macarena Gomez-Barris, The Extractive Zone: Social Ecologies and Decolonial Perspectives, Durham, North Carolina, Duke University Press, 2017, p. 83. While this book concerns South American Indigenous territories, her analysis is pertinent to a transcontinental perspective.

is Karyn Recollet, "Gesturing Indigenous Futurities through the Remix," Dance Research Journal, vol. 48, no.I, April 2016, p. 9I, full text available at: https://www.cambridge.org/core/journals/dance-research-journal/article/gesturingindigenous-futurities-through-the-remix/E8BE8C4 $\mathrm{B}_{28} \mathrm{D}_{90}{ }_{37} \mathrm{FC}_{35} \mathrm{CD}_{65} \mathrm{C}_{2} 642 \mathrm{~F}_{23} \#$ (accessed 22 May 2019). 
These remix performances work the frictions around collective memory as cultural artefact, which I will explore as Tagaq's sensational pedagogy of decolonial love, and Maddin's carefully legalized re-visionings of one of the most expropriated cities in the world. The remix's tactical intimacy lies in its micropolitical incursions into hegemonic social forms, including received narratives and orientations of sound and vision. Remixes can be testing grounds for practicing how else things can be, through creative appropriations of the matters at hand underpinning audiovisual media forms: most notably, time itself. Critically, these tactics refuse to disaggregate form, content, circulation, and reception. The non-normative temporalities of remix may provide pragmatic opportunities to experiment with altering unliveable conditions of haunting, as the site of their political, performance, and pedagogical interventions.

\section{REMIX PRACTICES}

Remix is "the practice of appropriating, decontextualizing, and recontextualizing media content to create new meanings." ${ }^{16}$ A remix takes a flexible approach to distinguishing raw materials from archival provenance; material support versus content loses a defining force. Performance expands the limits of what is remixed, including corporeal and environmental sites of reception and dissemination. The chronic collage of remix includes the audience's presence and their archive of past experiences. The contemporary serves as a processor, rather than receiver, for historical materials of different temporal origins.

In criticism, the remix is often linked to political effects to subvert dominant structures of power through direct participation in media form. Though bound to questions of copyright, authorship, and the challenges of new forms of circulation, this view can overestimate the remix's democratizing force, failing to understand the affective hurdles to access produced by "the symbolic domination of the public sphere by the image." ${ }^{17}$ As Grayson Cooke notes:

${ }^{16}$ Corey Creekmur, Melanie Kohnen, Jonathan McIntosh, Lori Morimoto, Katherine Morrissey, Suzanne Scott, and Louisa Stein, "Roundtable: Remix and Videographic Criticism," Cinema Journal, vol. 56, no. 4, Summer 2017, pp. 159-184, full text available on Project Muse: https://muse.jhu.edu/article/666239/pdf (accessed 22 May 2019).

${ }_{17}$ Grayson Cooke, "Performing Archival Remix in Outback and Beyond," International Journal of Performance Arts and Digital Media, vol. II, no. I, 2015, p. I03. 
consciously turning to the material that already exists in the social and cultural field to fund new production must be one of the core responsibilities of the media artist today. But this responsibility is about more than simply owning up to the inevitability of influence and intertextuality, or protesting regimes of intellectual property control; it has to do with an interrogation of the archive and its social function. ${ }^{18}$

Considering these two remixes, which explicitly take up questions of space and place, allows us to think of the work of time as a disrupting force against sedimented claims of ownership, divorced from relations of care.

Thus, the remix is inseparable from questions of affect, as an immaterial force. How might remixes open onto the more ambiguous claims of affective feeling, corporeal inclination and keen attentiveness to media archives as scenes of the limits of access to representation? In foregrounding affect, I understand re-animation not as restorative, but as a force that troubles what Mel Y. Chen has termed the "animacy hierarchy," how we understand agency and conceptually arrange "human life, disabled life, animal life, plant life, and forms of nonliving material in orders of value and priority" ${ }^{19}$ in a way that critically reveals the inequities within and beyond the human. Chen's analysis cuts transversally across life forms and troubles easy distinctions about "which things can or cannot affect - or be affected by — which other things within a specific scheme of possible action," ${ }_{20}$ complicating media ethics around "giving voice" and the representation of agency. Remixes often rely on a reanimation of a lifeforce that is ambiguously embodied in material forms of audiovisual artifacts, highlighting the ways in which an audiovisual atmospherics is a critical life support in the twenty-first century. Beyond representation, media ecologies are communal resources, though inequitably distributed. Chen's work considers how boundaries of form are inseparable from ecological actants that animate them.

Chronic collage ${ }^{2 \mathrm{I}}$ is a boundary practice of disturbing animacy hierarchies by activating incorporeal dimensions of media forms (e.g. the "storage device" of spectatorial

${ }^{18}$ Ibid., p. IO2.

${ }^{19}$ Mel Y. Chen, Animacies: Biopolitics, Racial Mattering, and Queer Affect, Durham, North Carolina, Duke University Press, coll. "Perverse Modernities," 2012, p. I2.

${ }^{20}$ Ibid., p. 30.

${ }^{21}$ For further discussion of chronic collage see Toni Pape, Noémie Solomon, and Alanna Thain, "Welcome to This Situation: Tino Sehgal's Impersonal Ethics," Dance Research Journal, vol. 46, no. 3, December 2016, p. 89-100; and Alanna Thain, Bodies in Suspense: Time 
memory, or live performance) alongside their foregrounding of material conditions of existence. Chronic collages employ duration and endurance. How might we use the space between live performance, cinema, and our archive of media memories to assess the "singularity" of these temporal objects, or how they create novel relations through anarchival impulses?

Chronic collage is an anarchival technique. I developed the concept of the anarchival to address how media movements produce ambiguous forms of embodiment that share time between bodies both cinematic and corporeal, remixing social and spatial ecologies. ${ }^{22}$ Attending to time in chronic collage asks: What can media do as a soft technology of somatic fabulation? Gilles Deleuze adapts Henri Bergson's term fabulation ${ }^{23}$ to address how images might function as a political and creative mode for social assembly, generating new lifeworlds by falsifying established truths to make place for a "people to come." 24 "People to come" is Deleuze's alternative to a politics of representation - urgently relevant for Indigenous lives too often coded as disappearing or past, or bodies recoded as "haunting" landscapes of urban exclusion. Fabulation falsifies established ideas and agentic positions in a process that tends towards new social articulations. Fabulation as creative tactic renders form dynamic, reopened to the improvisatory impulse of life itself against biopolitical strategies of control. In these reperformances, which respectively resist the deadening force of "ethnographic taxidermy” ${ }^{25}$ as inadequate to Indigenous resurgence in the North and deploy a scattershot anachronism against the progressive ghosting of San Francisco as a city of social resistance, fabulation names the future-oriented actions of anarchival investigations.

and Affect in Cinema, Minneapolis, Minnesota, University of Minnesota Press, 2017, especially Chapter 4 "Time Takings: Suspended Reanimations and the Pulse of Postdigital Cinema," pp. 265-66

${ }^{22}$ See Thain, 2010.

${ }^{23}$ See Henri Bergson, The Two Sources of Morality and Religion, transl. and ed. by R. Ashley Audra and Cloudesly Brereton, London, Macmillan and Co, 1935, full text available at: https://archive.org/details/twosourcesofmora033499mbp/page/nI (accessed 22 May 2019); Gilles Deleuze, Bergsonism, transl. by Hugh Tomlinson and Barbara Habberjam, New York, Zone Books, 1991; for the concept of fabulation, see Gregory Flaxman, Gilles Deleuze and the Fabulation of Philosophy, Minneapolis, Minnesota, University of Minnesota Press, coll. "Powers of the False, 2012; and Ilona Hongisto and Toni Pape, "Unexpected Artivism: The Fabulatory Function in Kumaré," Studies in Documentary Film, vol. 9, no. I, 2015, p. 69-83.

${ }^{24}$ Gilles Deleuze, Negotiations 1972-1990, transl. by Martin Joughin, New York, Columbia University Press, 1997.

${ }^{25}$ Fatimah Tobing Rony, The Third Eye: Race, Cinema, and Ethnographic Spectacle, Durham, North Carolina, Duke University Press, 1996, p. Ioo. 


\section{TO CATCH A CRY}

Fatimah Tobing Rony describes the ending of Flaherty's Nanook of the North as an extended image of ethnographic taxidermy, when the sleeping visage of Nanook (Allakariallak) is crosscut with howling, iced huskies and a snowy and unoccupied Arctic landscape. ${ }^{26}$ Human, animal, and environment are editorially isolated from each other. Demonstrating how visual media uphold dominant regimes of truth, ethnographic taxidermy describes the "utopic" impulse to make "that which is dead look like it is still living," ${ }^{27}$ because of Flaherty's desire to show the Inuit not as they were in 1922, but as they had been, both in actual practices (e.g. walrus hunting with harpoons rather than guns) and in colonialist fantasies. "The utopia of life-like reproduction depends upon and reacts to the fact of death," ${ }^{28}$ where utopia's noplace elides the actual evacuation of lifeworlds through forced resettlement of seminomadic Inuit. The paradoxical reaction of romantic primitivism - "that person is alive"29-is easier if they are already believed to be dead, and serves to biopolitically capture the body's primary affective capacity: to change and "to make sensational, via a thinking-feeling, its own relation to time." ${ }^{\circ}$ The film's famous scene of Nanook biting into a gramophone record, as if unaware of its use, condenses the unsustainability of this forged image of Indigenous ignorance and the indigestible record of modern media recording. Tagaq has cited this scene as one of the most egregious motivations for her reperformance. ${ }^{31}$

For Deleuze, fabulation, which I see as the labour of chronic collage, should replace utopian thinking. ${ }^{32}$ In Tagaq's always renewed live-action soundtrack, fabulation's anarchival impulse short-circuits and reroutes a taxidermic impulse. This live performance builds a soft architecture of engagement in its expanded cinema. It complexifies, rather than connects, two moments in time, multiplying temporal filters, stretching and delaying, across the gap of sound and image, the questions of what moves, what lives, and what remains. In an August 2018 performance, during the film's final sequence, Tagaq snaked her arm into the air such that her hand intruded on the bottom of the screen. Her silver sequined dress dramatically refracted the projected light. Tagaq's performance invited a transversal and transpersonal

\footnotetext{
${ }^{26}$ Ibid.

27 Ibid., p. IоI.

${ }^{28}$ Ibid.

29 Ibid.

30 Thain, 2017, p. 14.

${ }^{3 \mathrm{I}}$ Gordon, 2014.

${ }^{32}$ Deleuze, 1997, p. 174.
} 
imagination of sound that moves across breath: the dog's howl, the howling wind, and Nanook's stillness. But Tagaq's vocalizations, rhythmic and guttural, soft and babbling, held off and held back a mimetic rendering of the sound, stretching the space between film and performance, failing to sync up. Power rippled down the outstretched antenna of Tagaq's arm, pulling in the film's affect and building suspense. When she finally arced back her head and released a howling cry, it did not simply sync up with the animal, human, or environment onscreen in mimetic empathy; indeed, there was a miss between image and sound. Instead, the dynamic form animated the anarchival impulse of the work's chronic collage.

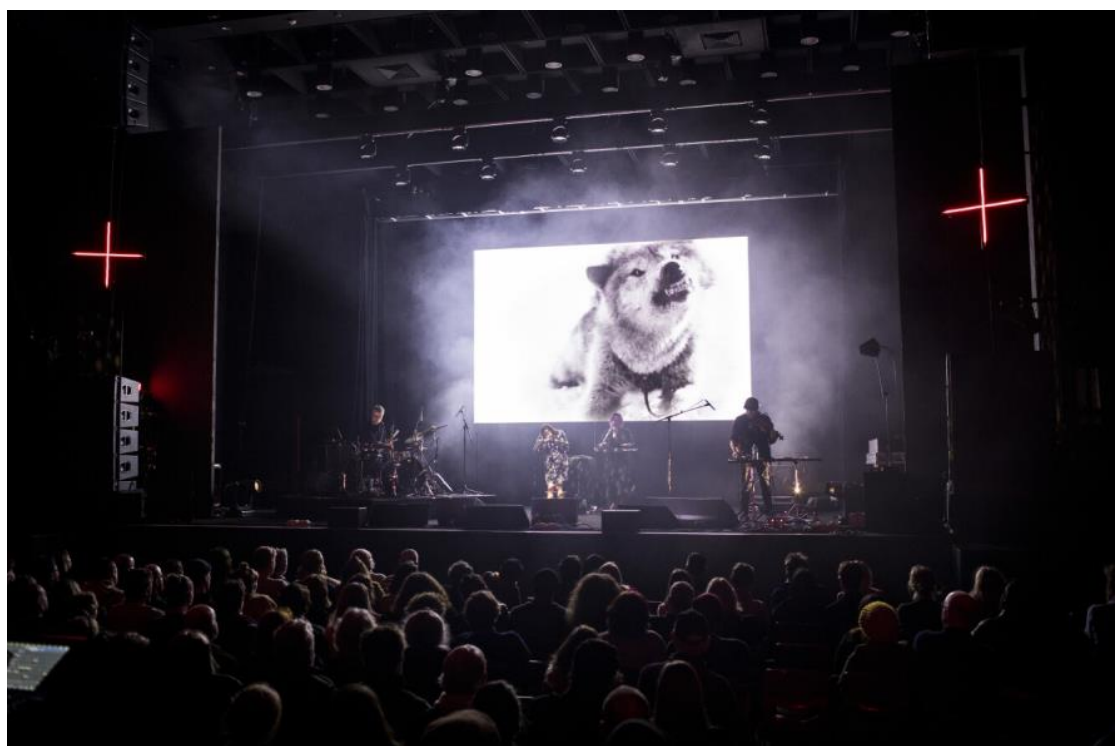

Fig. 4. Tanya Tagaq, Nanook of the North at the Dark Mofo Festival, June 8, 20I8. Photo Credit: Dark Mofo/Rémi Chauvin. Image: Courtesy of Dark Mofo, Hobart, Tasmania, Australia.

This instant of "generative cinema" produced an ecological embodiment, which, unlike taxidermy, did not present an image of time statically held together in a singular form. In other words, the experience of the new soundtrack performance generated disjunctions (collage's edges) that made more space for life. In a redistribution of the animacy hierarchy exceeding the question of who speaks, Tagaq's performance does not simply give voice to the human actors on screen, but produces a media ecology traversing the subjective, the social, and the environmental. Breath is inseparable-though not collapsed into-song, wind, 
howl, silence. This transversality is what Kristin Simmons describes as "porosity" in her essay "Settler Atmospherics":

Porosity thus becomes a site of potential, exposure, and entanglement all at once, questioning the stability of our worlds, human and nonhuman. In a porous relationality - attuning to how others (cannot) breathe, our haptics are enhanced and we develop capacities to feel one another otherwise. ${ }^{33}$

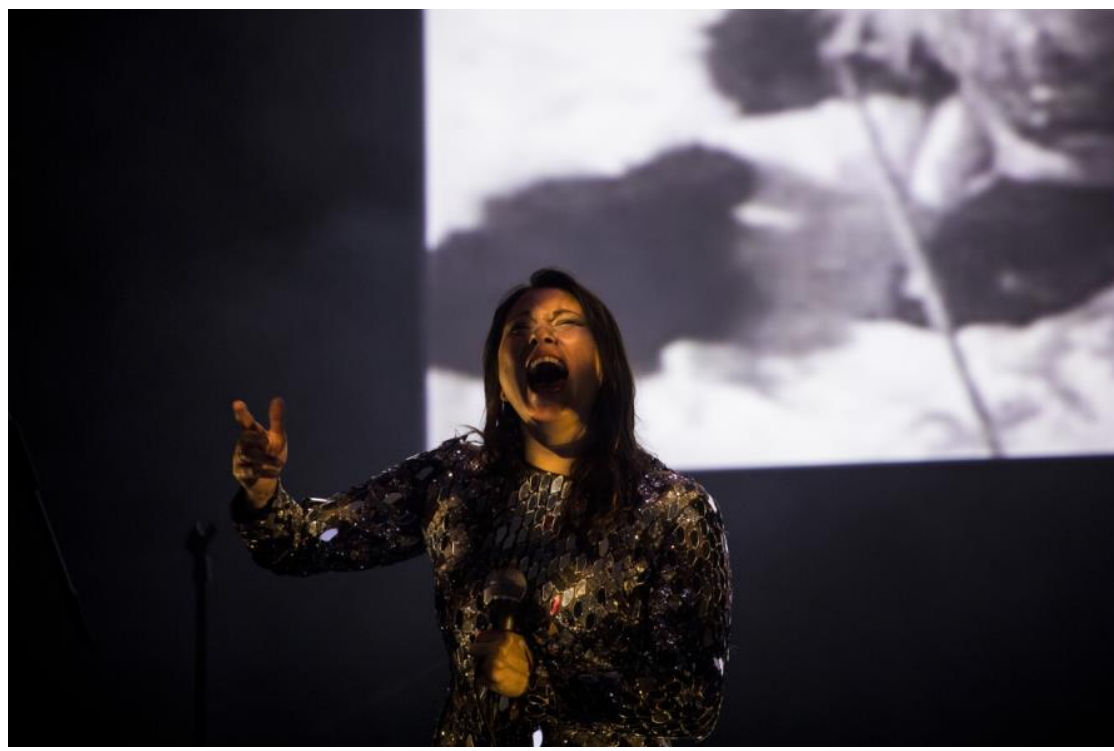

Fig. 5. Tanya Tagaq, Nanook of the North at the Dark Mofo Festival, June 8, 2018. Photo Credit: Dark Mofo/Rémi Chauvin. Image: Courtesy of Dark Mofo, Hobart, Tasmania, Australia.

Tagaq's Nanook is a decolonial "chronic collage,” rendering palpable the lived experiences of violence and dispossession yoking visual culture, colonialism, and documentary's truth claim. The labour of performance reopens breathing room, repossessing Flaherty's images through Tagaq's unique musical style and collaborative improvisation. Tagaq has developed a visceral, extended solo take on katajjaq, Inuit throat singing traditionally performed as a playful battle between two women. As Vanessa Blais-Tremblay notes, "Crucially, a throat game is less a musical

33 Kristen Simmons, "Settler Atmospherics," Member Voices, Fieldsights, November 20, 2017, https://culanth.org/fieldsights/I22I-settler-atmospherics (accessed 22 May 2019). 
genre than a game. It has, if not a competitive, then a strongly dialogical character: whoever can produce the most interesting sound qualities and show the most respiratory endurance wins the game." 34 Throat singing is also a vocal force that acts upon animals in the hunt, imitates environmental sounds and serves as a lullaby, in a transversal movement expanding the limits of domesticity. ${ }^{35}$ Tagaq's style also draws on contemporary electronic music, confounding the organic and technological. Indeed, the origin story for her musical career conflates recording media, material records, and affect; she describes receiving a cassette tape from her mom of Inuit throat singing while in school, and, through a powerful mixture of homesickness, childhood memories of the technique, and labour, taught herself a solo version of that shared technique.

What if we were to take the traditional, reified, thought-to-be-disappearing subject of anthropological and governmental capture- "the native" of ethnographic film like, for example, Nanook of the North (Flaherty 1922) - and imagine the meaning and significance of these representations of nativeness to us? What is the value of this, what is the lesson, what is the aesthetic that will produce emotions that suggest pleasure, filmic joy? Who is Nanook of the North for? How might this value and meaning change based on who is watching this classic of ethnographic film history? ${ }^{26}$

Simpson's question speaks to how Tagaq's performance as an engagement of tertiary forms of retention might be bound to novel forms of feeling that sustain, rather than capture, life. ${ }^{37}$

34 Vanessa Blais-Tremblay, “'Don't Pocahontas Me': Politics of Improvisation in Tanya Tagaq's Throat Games with Concert-Stage String Ensembles," unpublished manuscript, 2019, p. 5 .

35 Serge Lacasse, Monique Desroches, and Sophie Stévance, Quand la musique prend corps, Montreal, Presses de l'Université de Montréal, 20I4, p. 3II.

${ }^{36}$ Audra Simpson, “'Tell Me Why, Why, Why': A Critical Commentary on the Visuality of Settler Expectation,” Visual Anthropology Review, vol. 34, no. I, Spring 2018, p. 6o, full text available at : https://anthrosource.onlinelibrary.wiley.com/doi/full/Io.InI/var.I2I53 (accessed 22 May 2019).

37 Tertiary memory is a term drawn from the work of Bernard Stiegler, to describe an exteriorization of memory into technical objects such as film, sound recordings and photographs, and developed across the three books of his Technics and Time series: Technics 
Tagaq's performance troupe is positioned in front of the projected film, fully visible to the audience. As much a visual as a sonic spectacle, it alternately competes with the film image and accompanies it. The musicians co-compose the film. While acknowledging the critical force of Rony's analysis, Michelle $\mathrm{H}$. Raheja has documented how Inuit also co-produced images, rather than simply passively receiving the gaze, in an analysis directly relevant to Tagaq's anachronistic "collaboration." ${ }^{8}$ Beyond reclamation, Tagaq's version of Nanook is an insistent double vision that disorients in an activist project of anarchivally recharging the past. Both Raheja's research and Tagaq's "research-creation" exemplify what Eve Tuck and Crystal Fraser call for in response to current demands to decolonize archives. Skeptical of an ahistoricizing risk, their alternative is a critical chronic collage:

Acknowledging the inherent colonial paradigms that inform and shape the archives as institutions, we propose moving away from the question of decolonizing the archives themselves and suggest instead applying a historically informed critical decolonial sensibility in our engagement with the archives. 39

Tagaq's work is at once double vision and historically informed side-eye of a film she both reviles and claims as a family album. As VK Preston describes this:

it is a deft and important historiographical labour that, a century after Nanook, counters and discloses ethnographic cinema as a rehearsal grounds for cultural erasure-as well as reclamation. Sound's capacity to traverse bodies and insinuate itself across the senses here reconfigures the sway of the

and Time, I: The Fault of Epimetheus, Stanford, Stanford University Press, 1998; Technics and Time, 2: Disorientation, Stanford, Stanford University Press, 2008; and Technics and Time, 3: Cinematic Time and the Question of Malaise, Stanford, Stanford University Press, 2010.

${ }_{38}$ Michelle H. Raheja, Reservation Reelism: Redfacing, Visual Sovereignty, and Representations of Native Americans in Film, Lincoln, Nebraska, University of Nebraska Press, 20Io.

39 Crystal Fraser and Zoe Todd, "Decolonial Sensibilities: Indigenous Research and Engaging with Archives in Contemporary Colonial Canada," Decolonizing Archives. L'Internationale Online, Is February 2016, para. 2, https://www.internationaleonline.org/research/decolonising_practices/54_decolonial_sensi bilities_indigenous_research_and_engaging_with_archives_in_contemporary_colonial_cana da (accessed 22 May 2019). 
record, reverberating with Tagaq's power as a vocalist and, in flickering light, the plundering and resurgence of the north. ${ }^{4 \circ}$ Jesse Zubot to create the new soundscape. The improvised performances include loops and samples generated before the first performance, between media and memory. Tagaq says:

I watched the film four times, and responded vocally and composed my own melodies and stuff like that to the film. And then sent that all off to Derek and he took that and put field recordings over it from Nunavut. And he processed my voice and it's just a really nice kind of bed that we get to, like a sonic bed we get to lay on while we're improvising on top of it. ${ }^{41}$

Tagaq's homely image doesn't quite do justice to the performance's incredible energy! The distinction between live and recorded lies not between archive and performance, or visuals and sound, or Flaherty and Tagaq. Instead, Tagaq creates an audiovisual collage of temporalities, citations, affects, and rhythms, playing with her own memories and the anachronistic sound match of field recordings from the visual film's future troubling an "animacy hierarchy" across images and embodiments. It is not simply her live presence that grants her privileged access to meaning-making, nor are Flaherty's images simply unthreateningly dead and inert. Between sampling, remixing, and reperformance, chronic collage tactically mobilizes time's unruly affective agency.

Such affective agency is Tagaq's sensational pedagogy of "decolonial love," an expression elaborated by Anishinabe artist and educator Leanne Betamosake Simpson. Simpson fabulates this term from Junot Diaz, in a chronic collage: "[W]henever I read him, I'm always creating counter narratives in my head of what his female lovers would be thinking and doing." ${ }^{42}$ Decolonial love, an otherwise love, is a way to explore what

$4^{\circ}$ VK Preston, "Tanya Tagaq in Concert with Nanook of the North" (review), Theatre Journal, vol.68, no. 4, December 2016, p.649, full text available on Project Muse: https://muse.jhu.edu/article/64540I/pdf (accessed 22 May 2019).

${ }^{4 \mathrm{I}}$ Cited by Gordon 2014.

${ }^{42}$ Tanaya Winder, "Falling Into Decolonial Love: An Interview with Leanne Simpson, Author of Islands of Decolonial Love: Stories and Songs," As/Us, no. 4, 20I4, https://asusjournal.org/issue-4/interview-with-leanne-simpson/(accessed 22 May 2019). 
Simpson calls "the nation within our bodies." 43 If, as Wolfgang Ernst has argued, the modern archive is closely "related to the territorial nation state" 44 with its mobilizing biopolitical logic of policed borders, extraction, and dispossession, Simpson's decolonial love at work in Tagaq's performance insists on the imbrication of bodies and land in an insistently political "ecology of intimacy." 45 Tagaq's performance, which often begins with a preamble situating the 1922 film in dialogue with the current lived conditions of the Inuit (lack of food security, forced displacements, Southern antagonism towards sustainable practices such as the seal hunt, the ongoing legacy of colonial violence, alongside histories of survival, creativity, and care), stages this ecology of intimacy against the backdrop of the images, asking us: What else is there to see? As Erica Violet Lee writes:

As Indigenous people in colonial worlds, our vulnerability is non-consensually consumed and it is rarely ours to own. Daring to claim love and desire for Indigenous bodies in the face of ongoing colonialism is a liberatory act of vulnerability. Allowing love to flow beyond the edges of our skin (in the form of touch), our lips (in the form of language), and our eyes (in the form of tears) is necessary and radical in a world where we're taught to believe those borders are impassable. ${ }^{46}$

The intimacy of ecological embodiment overflows the self, reasserting relation across subjective, social, and environmental ecologies.

Tagaq's performance pedagogy of decolonial love uses chronic collage to hold open the multiple ecological layers of performance. In doing so, she stages the

43 Ibid.

44 Wolfgang Ernst, "Radically De-Historicising the Archive. Decolonising Archival Memory from the Supremacy of Historical Discourse," Decolonizing Archives. L'Internationale Online, p. Io, full text available at: https://www.internationaleonline.org/media/files/o3-decolonisingarchives.pdf (accessed 22 May 2019).

45 Leanne Simpson, “I Am Not a Nation State," Leanne Betasamosake Simpson (personal blog), 6 November 2013, https://www.leannesimpson.ca/writings/i-am-not-a-nation-state (accessed 22 May 2019).

${ }^{46}$ Erica Violet Lee, "Land, Language, and Decolonial Love," Red Rising Magazine, cited in "Red Rising Magazine: Land, Language and Decolonial Love," Moontime Warrior (personal blog), 22 November 2016, https://moontimewarrior.com/2016/II/22/red-risingmagazine-land-language-and-decolonial-love/ (accessed 22 May 2019). 
connected logics of extraction and exhaustion, linking body and land at the nexus of liveability. While Tagaq's performance clearly dialogues with contemporary discourses of reconciliation, 47 it also sharply asks, following Audra Simpson's question above: Who is this for? Robyn Taylor Neu found Tagaq's album Animism (2014) was consistently described as "authentic" and as evidence of a successful reconciliation between settlers and Indigenous cultures, which risks:

falsely sublimating persistent empirical tensions; a problem of (settlercolonial) relation to paraphrase John Durham Peters ${ }^{4}$ becomes "a problem of proper tuning or noise reduction" requiring only "the perfect medium to bring aboriginal and non-aboriginal communities together" [...] Here, under the rubric of reconciliation as commensuration, empty affirmation of an Indigenous voice may indeed be "all there is." 49

Tagaq rejects reductions of her artistry to "authentic" expressions of traditional culture; in describing this work as chronic collage, I attend to the incommensurable temporal dynamics Tagaq's project animates.

Tagaq's embodied performance, staging "the nation within our bodies," makes the work exceptionally powerful in its fragility, gambling on the audience's ability to anarchivally carry it. Her soundtrack, improvised anew each time, exists only as performance in relation to the visual record. It will not circulate as a new soundtrack to the original film. Such ephemerality is the risk, strength, and demand of working with a colonial archive like Nanook. It puts enormous demands on the performing body of Indigenous subjects. In Tagaq's adaptation of traditional throat

47 In 2008, the Canadian government launched the Truth and Reconciliation Commission (TRC, http://www.trc.ca/) as a mandatory outcome of an investigation into the impact of the Canadian Indian Residential School system, which was determined to be an act of cultural genocide through the theft and abuse of approximately I50,000 Indigenous children. The TRC, completed in 20I5, proposed steps towards "reconciliation," a term that has been roundly criticized for failing to acknowledge the ongoing effects of colonialism on Indigenous peoples today as well as the persistence of colonial practices under new forms (for example, the excessive number of Indigenous children in foster care as a new iteration of residential schools). Tagaq's work is frequently in deeply critical engagement with the question of reconciliation.

${ }^{48} \mathrm{John}$ Durham Peters, Speaking into the Air: A History of the Idea of Communication, Chicago, Chicago University Press, 1999.

49 Robin Taylor-Neu, “'All There Is': The Reconciliatory Poetics of a Singing Voice," American Anthropologist, vol. I20, no. I, March 2018, p. I2, https://anthrosource.onlinelibrary.wiley.com/doi/epdf/Io.III/aman.I3003 (accessed 22 May 2019). 
singing, she transformed a short-form call-and-response battle between two people into a solo performance-and an eighty-three-minute-long performance is exhausting to sustain. The critical political truth she speaks, and potential she fabulates, is that Indigenous subjects are required to be on the scene to make their voices heard. If Idle No More-an ongoing (since 20II) grassroots protest movement of Indigenous people across Canada with shared concerns of defending the land, resisting state violence and sustaining Indigenous resurgence-used techniques like flash mobs to stage temporary interventions in "public" spaces such as shopping malls to make Indigenous demands felt, it had the dual effect of also showing the ongoing vulnerability of Indigenous claims where pipelines and other expropriative forces only wait for Indigenous bodies to become exhausted or to be forcibly removed for business as usual to continue. What might Tagaq's performance, created and initially performed alongside the first movements of Idle No More, tell us about alternatives to political claims of occupation, ownership, and permanence, in a remix culture of persistence and survival? Its chronic collage is rippled with the vibration of a futurity that cannot only be dependent on constant supervision by Indigenous peoples to ensure that they are not forced, obscenely, offstage..$^{50}$ If this performance addresses how remix as reanimation can disrupt normative animacy hierarchies through chronic collage, how else can we see through and with "twenty-first century filters" to more sustaining lived ecologies?

so Here, one might think of the way that Tagaq, as well as other Indigenous culture makers, critics, and

curators have to constantly be “on scene” around Dominic Gagnon's 20I5 remix film, Of the North (which used Tagaq's music without permission), through social media, roundtables, editorials, etc., which constantly asked them to respond to that work, with little to no space for presentations of Indigenous self-representation. See, for example, Ezra Winton, "Curating the North: Documentary Screening Ethics and Inuit Representation in (Festival) Cinema," Art Threat, 17 December 2015, available on Winton's personal site, http://ezrawinton.com/2015/12/22/curating-the-north-documentary-screening-ethics-andinuit-representation-in-festival-cinema/ (accessed 2 June 2019); for an extended discussion of ethics of representation, see Michelle Stewart, "Of Digital Selves and Digital Sovereignty: Of the North," Film Quarterly, vol.70, no. 4, Summer 2017, p. 23-38, full text available at: https://fq.ucpress.edu/content/70/4/23.full.pdf + html (accessed 22 May 2019); for a discussion of the links between spatiality, the "white possessive," copy-left discourse, and ownership in this case, see Bruno Cornellier, "Extracting the Inuit: The Of the North Controversy and the White Possessive," American Indian Culture and Research Journal, vol. 4 O, no. 4 , p. $23-48$. 


\section{ECSTASY AND ECTOPLASM}

In 2018, images of Tagaq appeared onscreen at the Castro Theatre in San Francisco, in a "live documentary" performance by Sam Green of his film $A$ Thousand Thoughts (2018) about Kronos Quartet, Tagaq's collaborators on the performance project Nunavut. Green's live documentaries, which include Fog City (2013) about San Francisco's most famous weather entity, are an experimental format he terms "Utopian Cinema." As Norman Chan explains:

the word utopia literally means "no place," and Green's films only exist in the place and time that they're performed. Fog City will never screen in a movie theatre; it'll never be available on Netflix. It's an ephemeral film experience in which every screening is unique, and a business model that Green thinks could be the future of independent documentary filmmaking. ${ }^{5 \mathrm{I}}$

For Green, embodied presence is a sustainable art practice in an age of seemingly immaterial circulation. One year earlier, at that same site, Kronos Quartet performed live with Maddin's The Green Fog. In this strange sync, assembling this essay's actors on a single cinematic stage, I do not mean to suggest anything more than the corporeal coincidences that render time as lively, transindividual, and ecosophical.

An ecological sense of ambiguous embodiment characterizes chronic collage, where audiovisuality is a kind of sensible flesh. In Bodies in Suspense: Time and Affect in Cinema, ${ }^{52}$ I contend Hitchcock's Vertigo generates a double vision through Novak's dual performance as Judy and Madeleine. Her duplicity shatters precisely in the only space in the film that was not a found set in San Francisco: the bell tower where she dies (twice), added to the Mission San Juan Bautista via matte painting. Everywhere else, San Francisco provides a documentary support underpinning the film's phantom embodiments of possession, revenants, and zombies. I explored "free replays" of Vertigo from Chris Marker to Johan Grimonprez. Through the remix The Green Fog, I now ask: How does the performance aspect of this film as a chronic collage open onto an ecological point of view, where San Francisco's found landscape emerges under the pressure of contemporary expropriation?

${ }^{51}$ Norman Chan, "Sam Green's Fog City and the Live Documentary," Tested.com, 3 October 2013, https://www.tested.com/art/makers/458419-sam-greens-fog-city-and-livedocumentary/ (accessed 22 May 2019).

52 Thain, 2017. 
Rebecca Solnit maps San Francisco as a "cinema city," full of hauntings and losses, from Eadwaerd Muybridge to Sam Green, and more. ${ }^{53}$ Solnit's reflections are deeply nostalgic, but also speak to cinema's heterotopic suspensions of normal space and time. Echoing Roland Barthes, she describes the afterglow of exiting the movie theatre that carries one into a delicately cinematic night, or the enrapturing force of her neighbour's private microcinema, projected onto a sheet across his window into the street for all to silently see. Such untimely experiences, that for Solnit signal hauntings, I wish to read in The Green Fog as the disjunctions of chronic collage. Through Maddin's reperformance, I focus on the labour of embodiment in the film as chronic collage.

Since the turn of the century, Maddin has increasingly developed an archivoecological relation to an expanded cinema of performance. Brand upon the Brain! (2006) and My Winnipeg (2007) initially toured with live soundtracks. The 2010 (re)production of Maddin's 1989 film Tales from the Gimli Hospital Reframed, was presented at New York's Performa with a reimagined soundtrack and live narration. Maddin's necrophilic ecologies incorporate cinematic and corporeal bodies, activating audience memories of bygone eras not only in terms of style, technique, or genre, but also through the sensuous temporal textures of $16 \mathrm{~mm}$ prints worn out by years of projector runs. With The Green Fog, different mediums and eras rendered across sampled materials were treated like "palettes," evocative rather than referential. ${ }^{54}$

Maddin's approach is anarchival, generating a falsified archive of lost or dreamed cinema. Jamie Baron has argued that in "the archive affect" our desire for what is past is always accompanied by a recognition of what is lost. 55 But despite the saturated nostalgia seemingly coating Maddin's film, both his and Tagaq's works short-circuit the closed loop of pastness via fabulation's future-oriented force. Maddin's forays into "live" cinema performance are not a nostalgic pastiche of a golden age of a cinema increasingly remote from current practice. Rather, they engage the contemporary cinematic ecology of "collaborative remix zones." These filmperformances confound temporal orientations by creating new circulatory contexts for audiovisual images, and through reworking the medium, redouble cinematic

53 Rebecca Solnit, Infinite City: A San Francisco Atlas, Berkeley, California, University of California Press, 2010; see p. 23-30 on "Cinema City."

54 Varty, 2017.

55 Jamie Baron, The Archive Effect: Found Footage and the Audiovisual Experience of History, New York, Routledge, 20I4. 
form through affect in a movement "back to the future." This future orientationgenerative speculation or a prospective storytelling-is what I mean by fabulation. My Winnipeg's "docufantasia" remixed an anarchic restaging of the archive of personal, collective, and urban histories. As Maddin described this: "It is a historical, mythological look. And when I say mythological I don't mean it's not true. I just mean it has been processed by the passage of time." 56 Fabulation offers a way to think the question of processed by time other than as decay.

Maddin has long been fascinated by fabulation, in particular in respect to the forger. Deleuze identifies the forger as a conceptual persona who gives way in fabulation to the artist through acts of intensive depersonalization. This is a mode of immanent evaluation or creation, moving from criteria of truth and falseness to constant regenerations of modes of subjectivation. ${ }^{57}$ Such depersonalizations traverse The Green Fog's subjective, social, and environmental ecologies of character, actor, and audience memory in the restless phantoms of Jimmy Stewart and Kim Novak and their sampled mediums, from Chuck Norris to Michael Douglas.

In "The Storyteller," Walter Benjamin diagnoses the decline of storytelling as the result of the loss of "the ability to exchange experiences." ${ }^{8}$ At the end of The Three Ecologies, Guattari's manifesto for renewed collectivity and ecosophical thought, he cites Benjamin to discuss how "new stories of the permanent recreation of the world" 59 can replace origin stories of Biblical genesis:

[Storytelling] does not aim to convey the pure essence of the thing, like information or a report. It sinks the thing into the life of the storyteller, in order to bring it out of him again. Thus traces of the storyteller cling to the story the way the handprints of the potter cling to the clay vessel. ${ }^{60}$

Storytelling resists being simply information when it is processed by time. Storytelling activates the reader; Benjamin writes:

\footnotetext{
${ }^{56}$ My emphasis. James Nadeau, "Interview with Guy Maddin,” Big, Red and Shiny, 13 July 2008, http://bigredandshiny.org/2749/interview-with-guy-maddin-director-of-mywinnipeg/ (accessed 22 May 2019).

57 Deleuze, 2005, p. I4I.

$5^{8}$ Walter Benjamin, "The Storyteller: Reflections on the Works of Nikolai Leskov," Illuminations: Essays and Reflections, New York, Schoken Books, 1969, p. 83.

59 Guattari, 2005 , p. 67.

${ }^{60}$ Ibid.
} 
the most extraordinary things, marvelous things, are related with the greatest accuracy, but the psychological connection of the events is not forced on the reader. It is left up to him to interpret things the way he understands them, and thus the narrative achieves an amplitude that information lacks. ${ }^{61}$

In The Green Fog, the documentary conceit of images "shot on location" subtends the film's ability to prompt imagination, beyond information.

At the beginning of The Green Fog, a machine's dial is switched from talk to listen (see Fig. 6), an invitation to switch sensory modalities from capturing information and communication to attending. Throughout, almost all dialogue from sampled scenes is eliminated. Though Vertigo is notoriously quiet, full of sequences of stalking, watching, and waiting, in The Green Fog words are explicitly excised, leaving behind the work of breath and the odd aftermath and anticipation of sense-making, the before and after of speaking distorting faces to marvelous effect. Maddin describes a muted Chuck Norris as "Bressonian" in his body's amateur reperformance of Scottie's "catatonia." 62 Sense resists extraction; meaning remains in the body in microarchives of expression. Content and expression chase after each other, as in Tagaq's soundscape; in editing mimetic matches are underplayed in favour of a sonic ecology of corporeality, organic and technological.

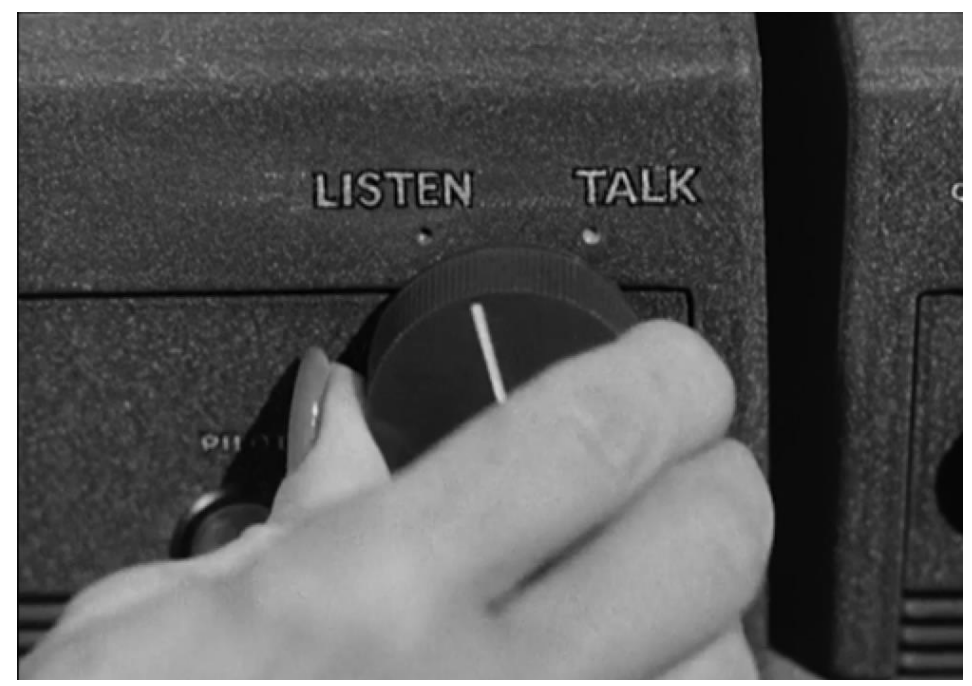

Fig. 6. Photogram of The Green Fog (Guy Maddin, Evan Johnson, and Galen Johnson, 2017).

\footnotetext{
${ }^{6}$ Benjamin, 1969, p. 88

${ }^{62}$ Cited by Varty, 2017.
} 

Boys video, from animated motion studies by Eadweard Muybridge to Star Trek IV, The Green Fog emerged from an invitation by the San Francisco Film Festival to pay homage to the city's long afterlife on screen. The festival's lawyer negotiated and approved fair use of the images. Initially, Maddin and the Johnsons thought to restage historical highlights, such as the AIDS crisis, but instead remade that most fabulative cinematic machine, Vertigo. In a syncopated exchange across plot points, iconic images, and found locations, the remake manages to be both expansive and contractive at once. Its "historical, mythological look" repeatedly conveys the processing of time, pulsing between myth and materiality, homeopathically undercutting Vertigo's closed onericism precisely through the open, associative dreaming of the remix.

Of the film, Maddin declared: "How delightful to move archetypes around like so much furniture in a dream!"63 evoking the hilarious scene of the arranging of dead father's body in Maddin's old family home in My Winnipeg, when past and present are ludicrously embodied and insistent. Thus section one of The Green Fog is entitled "Weekend at Ernie's," affectively deranging Madeleine’s ghostly allure, first witnessed at Ernie's restaurant, via a comedy whose ongoing punch line is reanimation of the rotting corpse of a boss. Labour is never far offstage in this film, speaking to San Francisco's current place as the future of digital labour practices, reliant on a geographic segregation of working populations and the expropriative force of wealth. ${ }^{64}$

And yet, the green fog continues to work its magic, spread across the film. The Green Fog continually deflates Vertigo's alluring suspense, precisely through overly staged corporealities. Vertigo's traumatizing death of the policeman at the beginning of the film is stretched out like an overused elastic. Maddin inserts one clip from Vertigo, the rung of the ladder that opens the film (a minor choice that levels that film's precious untouchability) and then stretches out the chase scene across a whole host of rooftops, an entire variety of speeds and urgencies, and multiple actors until

\footnotetext{
${ }^{63}$ Cited in the program notes for The Green Fog, Vancouver International Film Festival, 24 August 2017. http://archive.viff.org/e-blasts/viff/2017/PR/06_MAD_PR.html (accessed 22 May 2019).

${ }^{64}$ See Andrew Norman Wilson's 2oIr video "Workers Leaving the Googleplex" for a contemporary media vision of this isolation: http://www.andrewnormanwilson.com/WorkersGoogleplex.html (accessed 22 May 2019).
} 
finally offering us a falling sequence that ends with the obvious, inelegant thud of a dummy. Where is this going?

Throughout, "character" moves across and between bodies, in a delirious expansion of Vertigo's duplicity. The Green Fog's chronic collage emerges in the interstices of body and city, in a series of ecological foldings. In the background, San Francisco looms and we have time, no longer distracted by plot or narrative suspense, to look around at it. The city becomes newly visible not as itself, and not even playing itself, but as a chronic collage where identifications-of actors, sites, source texts, historical eras, genres, and more-are as formulaic as detective work. In surveillant inserts that continually interrupt the film, via scenes that use recording and playback technologies to "zoom out” to a metalevel of observation, Rock Hudson bemusedly keeps watch in his role as Stuart McMillan, his I970s chic police commissioner from McMillan and Wife (1971-1977). These layers fail to stay in place. Near the end of the film, he casually starts a fire by tossing his cigarette into a bin full of film (the apocryphal fate of the first version of Nanook of the North); as the image burns down the whole world of San Francisco catches fire.
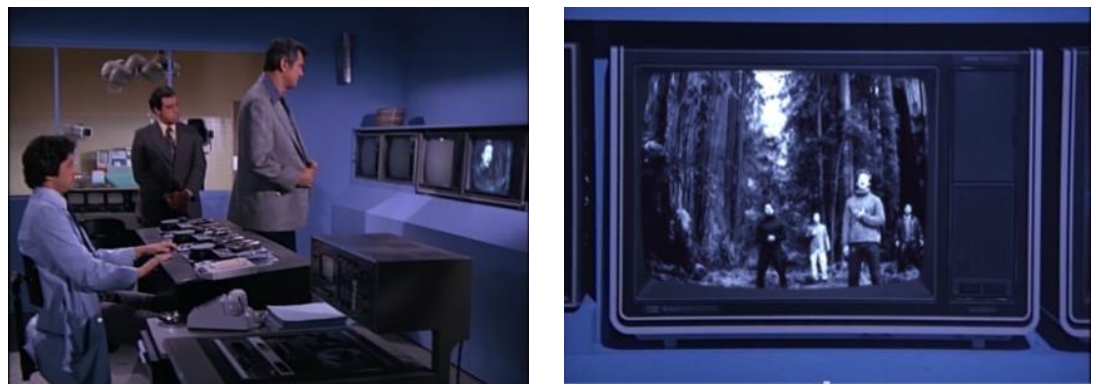

Fig. 7 and 8. Photograms of The Green Fog (Guy Maddin, Evan Johnson, and Galen Johnson, 2017.

Many sequences speak to the violence of the place-making that built the city. Looking out over the Golden Gate Bridge, a business mogul ponders: "Lives were lost making it, should it never have been built?" The city's reanimation acquires a fleshly quality, not as a container for living, but as a renewable material. A voiceover monologue (a rare instance of extended speech) on how the city has fallen into disrepair and dying slides seamlessly into the gendered territory of makeover, of daddies and daughters playing dress up, of a newscaster made over for the camera's gaze. The stakes of dispossession and ownership are critiqued via the 
ecological intimacy of Novak's Judy and the city, both subject to the murderous control of developer Gavin Elster in Hitchcock's film.

A preciousness of particularity is lost, in favour of seriality. This nextness keeps it from being a game of identification (information) and instead allows us to witness and participate in emergence. A series of churches, cathedrals, and bell towers are serial stand-ins for the mission where Scottie trails Madeleine. Against sacred space, any old tower will seemingly do. But as we follow Karl Malden into a cathedral during an episode of The Streets of San Francisco (1972-1977), a voice intrudes on the image in a rare monologue (Jack Palance in Sudden Fear from 1952), a long citation of Henri-Frédéric Amiel's meditations on depersonalization, inviting us to "let mystery have its place in you.” In seriality's interstices, time-pressure makes itself felt, creating such a nook for mystery. Immediately following this scene is a conversation between two women at a restaurant, the only line left intact: "I go to the museum every Saturday.” Maddin has described this scene as “a peek into Madeleine Elster's life, what her off-hours might be like and how concerned she might be about what she's doing,"65 part of the film's work to anarchivally reclaim lost time (off-hours, outside of a labour logic), for different stories to emerge.

If seriality and iconicity are subverted through attention, it is likewise the work of the body, its "off hours" labour as a material support for expression that drives the film. The film re-places proto-cinematic no-places of the body, such as Eadweard Muybridge's movement experiments in the Bay Area where he actually worked, anachronistically generating a fine confound with Vertigo's title credits by Saul Bass and the ground-breaking computer animator John Whitney, suspended between body and abstraction. Michael Douglas' naked bottom from Basic Instinct turns into one of Muybridge's walking nudes, white masculine nudity becoming visible and remarkably desireable rather than neutral. Then the scene is reframed as a screen image, as Douglas in The Streets of San Francisco watches a film and remarks, "You're looking good, Mike, ever thought about going into show business"? Maddin is a fascinating auteur of affective masculinity; the film's chronic collage re-places Scottie's scopophilic control, so often read as the hegemonic, unmarked masculine spectator, in the tender flesh of characters onscreen, making the view from nowhere embodied otherwise.

6s The Green Fog, press package, RDV Canada, https://rdvcanada.ca/wpcontent/uploads/gravity_forms/7955b4b6b37633fdbcf897f3d6esad9or/20I8/or/GREEN_FOG_PRESS_NOTES.pdf (accessed 22 May 2019). 


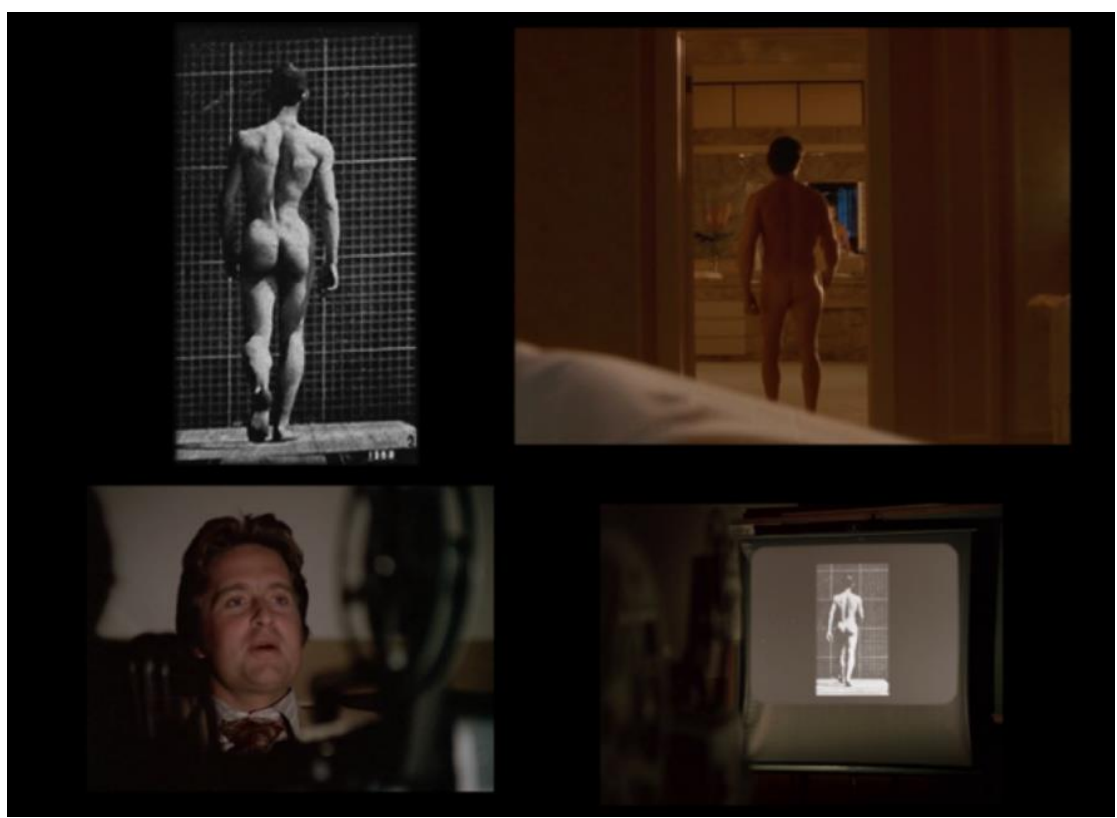

Fig. 9. Photogram of The Green Fog (Guy Maddin, Evan Johnson, and Galen Johnson, 2017).

Looping and relooping, the film confounds mapping to keep returning us to the scene. If in Vertigo, the real city as backdrop acquires the silent stillness of a movie set, in Maddin's version the found city contagiously sparks and cracks into life. Scale and duration become unhinged as affect and desire flood out from the closed world of character into the world. The green fog becomes rampant when a relentless series of women appear in doorways as the remade Madeleine. Phantom made flesh, the fog becomes fire, disaster escapes the couple form and zooms out through the city, as Scottie's passion, then betrayal and anger ignite first the hotel and then the entire city, through a conflagration that includes The Towering Inferno (1974). When betrayal is announced, it is as Donald Sutherland in Invasion of the Body Snatchers (1978), opening his mouth in the accusatory scream that reveals him as monster. His mouth becomes, in a cross-match cut, a tunnel; he is turned inside out in a psychotic geography of affect. Against media's extractive ecology, Maddin notes that

the Bay Area's not just had its soul sucked out of it by cameras over every decade of film history, but it's also been the cradle of so many different things: experimental film; a lot of activism; the Black Panthers were founded in the 
Bay Area; in the Summer of Love it was the epicentre of hippies; earthquakes... All this stuff appears and reappears. ${ }^{66}$

This logic of appearing and reappearing also describes and enacts the film's transversal narrative, animated by chronic collage. Each new find from the media archive reorients viewers; we feel the edges and search for what appears. Rather than a restorative approach, this interstitial filmmaking generates an emergent ecology of things that do not necessarily go together, but that fabulatively cling to the finished work as to the hands of the storyteller. Vertigo's obsessive, closed world of love reopens on a cosmic scale.

The chronic collage enacted in very different ways across these two works of remix operate through the inviting logic of the incommensurate, failing to neatly synthesize historical gaps between then and now. They fabulate futurity in their anarchival impulses. The Green Fog and Tagaq's resurgent revisioning of Nanook refuse a simple logic of extraction that sometimes subtends remix ecologies. Opening audiovisuality to a pedagogy of careful listening, both works find ways through the thick ecology of chronic collage to redress and address extractive logics of place, by animating the remix zones of embodied memory. 


\title{
Anarchival Images: The Labour of Chronic Collage
}

\author{
Alanna Thain, McGill UNiversity
}

\section{ABSTRACT}

This essay develops the concept of "chronic collage" through an analysis of two recent works of media reperformance: Tanya Tagaq's Nanook of the North (2012-) and Guy Maddin and Galen and Evan Johnson's The Green Fog (2017). Both are remixes commissioned as live performances by film festivals. Tagaq created a resurgent and resistant new soundtrack to Robert Flaherty's 1922 ethnographic film Nanook of the North and Maddin sampled media works shot in San Francisco to assemble a remake of Alfred Hitchcock's Vertigo (1958), with a live soundtrack by Kronos Quartet. Taking an ecosophical approach, this essay describes chronic collage as an anti-extractivist critical technique that plays on lived archives of moving image memory across sites of expropriation, exclusion, and contested history. A dynamic form, chronic collage names the attempt to animate the affective agency of temporal objects.

\section{RÉSUMÉ}

Dans cet essai, je développe le concept de collage chronique à travers une analyse de deux œuvres récentes de performance médiatique : Nanook of the North de Tanya Tagaq (2012-) et The Green Fog de Guy Maddin et Galen et Evan Johnson (2017). Ces « remixes » sont tous deux des commandes provenant de festivals de films, présentés à titre de performances. Tandis que Tagaq crée une nouvelle bande-sonore résurgente et résistante pour le film ethnographique Nanook of the North de Robert Flaherty, datant de 1922, Maddin échantillonne des films et des séries tournées à San Francisco pour refaire le film Vertigo d'Alfred Hitchcock, produit enı958, sur une bande-son signée par Kronos Quartet. À travers une approche écosophique, cet essai décrit le collage chronique comme une technique critique anti-extractiviste qui rassemble les archives vivantes des mémoires médiatiques traversant des sites d'expropriation, d'exclusion et d'histoire contestée. Comme forme dynamique, le collage chronique désigne la tentative d'animer l'agentivité affective d'objets temporels.

\section{BIOGRAPHICAL NOTE}

Alanna Thain is Associate Professor of cultural studies and world cinemas at McGill University in Montreal. She is the author of Bodies in Suspense: Time and Affect in Cinema (University of Minnesota Press, 20I7). At McGill, she directs the Moving Image Research Lab devoted to the study of the body in moving image media. Her current project is entitled Anarchival Outbursts, on the movement practices of post-digital media. 